\title{
Assessment of Hygiene in Collective Restaurants of Abidjan City
}

\section{(côte d'ivoire)}

\author{
Kouamé Kohi Alfred ${ }^{1}{ }^{2 *}$, Bouatenin Koffi Maïzan Jean-Paul', Boli Zamblé Bi Irié Abel', Coulibaly Wahauwouélé \\ Hermann', Djé Koffi Marcellin¹ \\ 'Department of Food Sciences and Technology, Laboratory of Biotechnology and food Microbiology, University of Nangui \\ Abrogoua, Abidjan, Côte d'Ivoire, Africa \\ ${ }^{2}$ Food Security Research Group, Centre Suisse de Recherche Scientifique, Abidjan, Cote d'Ivoire, Africa
}

*Corresponding author: Kouamé Kohi Alfred, Department of Food Sciences and Technology, Laboratory of Biotechnology and food Microbiology, University of Nangui Abrogoua, Abidjan, Côte d'Ivoire, Food Security Research Group, Centre Suisse de Recherche Scientifique, Abidjan, Cote d'Ivoire, Africa

\section{Abstract}

In the collective restaurants especially, the large quantities of food prepared on a daily basis mean that the basic rules of hygiene are often neglected. This is particularly true in our countries where the workforce often has a low level of training. The aim of this study was to assess the effectiveness of hygiene measures implemented in collective restaurants in the industrial zone of Yopougon (YOP1 and YOP 2) and a University Hospital Center (CHU) in Abidjan to ensure food safety for the guests. An inspection of three collective restaurants in the city of Abidjan was carried out. Sampling of the dishes as well as the diving areas and the hands of food handlers just before the completion of their task were carried out for the search and enumeration of Mesophilic Aerobic Germs, Staphylococcus aureus, coliforms and Salmonella. It was found that the food, the hands of the producers and the diving areas were contaminated with Mesophilic Aerobic Germs and Staphylococcus aureus. The loads ranged from 0 to $(2.6 \pm 0.3) 109 \mathrm{CFU} / \mathrm{g}$ and 0 to (1.57 \pm 0.1$) 106 \mathrm{CFU} / \mathrm{g}$, respectively. These loads were in compliance with EC standard No. 2073/2005. The food supplied by these restaurants was then of unsatisfactory microbiological quality.

Keywords: Collective restaurants, hygiene, microorganisms

\section{Introduction}

The reference to quality in its various meanings has become omnipresent, as the food product undergoes transformations and manipulations of which the consumer knows neither the nature nor the manipulators. The perceived quality of food, refers to a complex set of qualities expected from six aspects: nutritional, organoleptic, functional, social and health; not the least of these, the health quality of food refers to chemical and bacteriological safety. Collective restaurants are an economic activity that aims to ensure the common intake of food by a group of people outside the domestic setting. It includes the preservation and distribution of meals for collective use. Collective restaurants are defined as public or private establishments that provide a catering service free of charge or for a fee and where at least part of the clientele is made up of a community of regular consumers [1,2]. The safety of the food served by these establishments remains a major concern for the official services in charge of control. Ready-made meals are obtained from various foodstuffs, each with a specific flora. In mass catering, the respect of hygiene principles is a vital issue because food poisoning can be a sign of food insalubrity for the consumer. In industry, food poisoning can affect company performance through increased absenteeism [3]. In France between 1995 and 2005, 5847 outbreaks of TIAC, 80351 patients, 7364 hospitalisations and 45 deaths were recorded out of the total number of outbreaks, $64 \%$ of which occurred in collective or commercial catering. However, food poisoning mobilizes the media, which tend to amplify the accidents, the slightest toxi-infection is considered a disaster. The discredit thus thrown away can weigh heavily on the future 
of a company that prepares meals in advance [4]. This is why hygiene rules must be enforced in restaurants in order to prevent various food-borne diseases. The purpose of this work was to assess the effectiveness of the hygiene measures implemented in collective restaurants in the industrial zone of Yopougon and a University Hospital Center ( $\mathrm{CHU})$ in Abidjan to ensure food safety for diners.

\section{Materials and Methods}

\section{Study Sites}

Two restaurants from two companies in the industrial zone of Yopougon as well as a restaurant from a University Hospital Center (CHU) in Abidjan were selected for this study. The two restaurants in the Yopougon industrial zone provided food to the workers of these enterprises, while the University Hospital Center provided food to the patients of this center. These two restaurants were selected for their willingness to participate in this study, but also because of the economic importance of the businesses that host these restaurants. For the restaurant of the $\mathrm{CHU}$, it was chosen because the patients that the restaurant provides the meals are people at risk.

\section{Sampling}

An inspection of restaurants was carried out according to [5] method. The places where utensils were stored, and where food was stored before being served to customers were inspected. Ready-made and ready-to-serve dishes were collected from each restaurant. Samples were taken from the hands of the producers just prior to serving and from the surfaces of the dish washing areas and kitchen utensils using the method of Kouame et al. [6]. Three samples were taken in each restaurant. After sampling, the samples were placed in a cooler containing dry ice and transported to the laboratory within four hours of collection for the various analyses.

\section{Isolation and Enumeration of Bacteria}

The stock solution and decimal dilutions were performed according to the methods of [7]. For the analyses, ten grams (10 g) of samples were crushed and taken under sterile conditions created by the flame of a bunsen burner and mixed in a "stomacher" bag with $90 \mathrm{~mL}$ of buffered peptone water (AES Laboratoire, COMBOURG France) previously sterilized and used as diluent. Mesophilic aerobic germs (MAG) were counted on PCA (Plate count Agar) agar (Oxoid LTD, Basingstore, Hamsphire, England) after two (2) days of incubation at $30{ }^{\circ} \mathrm{C}$ according to AFNOR Standard NF V08051, 1999. The research and counting of Staphylococcus aureus were done on Baird Parker agar after one (1) day of incubation at $30{ }^{\circ} \mathrm{C}$ using [8] method. Violet crystal and neutral red biliated lactose agar (VRBL agar) was used for coliform count, after one (1) day of incubation at $30{ }^{\circ} \mathrm{C}$ for total coliforms and $44^{\circ} \mathrm{C}$ for faecal coliforms according to AFNOR Standard, NF ISO 4832 July 1991. The isolation and enumeration of Salmonella were carried out using Hendriksen [9] method in several steps. This was achieved by pre-enrichment in a non-selective medium, followed by enrichment in a selective medium and culture on selective agar. For enrichment in non-selective or pre-enrichment media, a quantity of Twenty-five grams (25) g of samples was homogenized with $225 \mathrm{~mL}$ of peptonned water in a sterile jar, incubated at $37^{\circ} \mathrm{C}$ for $24 \mathrm{~h}$. For selective recording, one milliter $(1 \mathrm{~mL})$ of the pre-enriched culture was transferred using a sterile pipette into $10 \mathrm{~mL}$ of previously prepared sterile Rappaport Vassililiadis. broth and incubated for $24 \mathrm{~h}$ at $37^{\circ} \mathrm{C}$. Salmonella enumeration was performed on Salmonella Shigella agar (Oxoid). Each enrichment culture was streaked on Shigella-Salmonella (SS) agar and incubated at $37^{\circ} \mathrm{C}$ for $24 \mathrm{~h}$. On Salmonella-Shigella agar, the presumptive colonies were colourless, transparent, with or without a black centre.

\section{Statistical Analysis}

The software R. 3-01 was used for the statistical analysis, ANOVA test and Duncan post-hoc test were performed at the significance level $5 \%$. This software made it possible to calculate the means, the standard deviations of the microbiological parameters. It also made it possible to compare the means of the microbiological parameters of the samples and to determine whether the differences observed in the means of the microbiological parameters are significant at the $5 \%$ threshold.

\section{Results}

Two restaurants in the industrial zone of yopougon will be rated YOP 1 and YOP 2, one at the University Hospital Center will be rated $\mathrm{CHU}$ for ethical reasons.

Microbial Load of the Menus, the Hands of the Producers, The Utensils and of the YOP1 Dive Zone

Ordinary sauce made from vegetables, tomatoes and fish, the kitchen utensils and the hands of the food service staff were free of microorganisms. The raw vegetables (starter dish) were contaminated with Mesophilic Aerobic Germs (MAG) and Staphylococcus aureus with respective loads of $(3.8 \pm 0.4) 107 \mathrm{CFU} / \mathrm{g}$; $(1.47 \pm 0.1) 106 \mathrm{CFU} / \mathrm{g}$. The special sauce (for use in the company), rice, ready-to-eat potatoes and the diving area were contaminated with Mesophilic Aerobic Germs (MAG) with respective loads of

Citation: Kouamé Kohi Alfred*, Bouatenin Koffi Maïzan Jean-Paul, Boli Zamblé Bi Irié Abel, Coulibaly Wahauwouélé Hermann, Djé Koffi Marcellin. Assessment of Hygiene in Collective Restaurants of Abidjan City (côte d'ivoire). 
(1.2 \pm 0.7$) 107 \mathrm{CFU} / \mathrm{ml} ;(3.2 \pm 0.1) 105 \mathrm{CFU} / \mathrm{g} ;(6.1 \pm 0.7) 105$ CFU/g; (9.1 \pm 0.8$) 106 \mathrm{CFU} / \mathrm{cm} 2$. All samples shall be free of Salmonella (Tables 1 \& 2).

Table1: Microbial loads in YOP1 menus.

\begin{tabular}{|c|c|c|c|c|c|}
\hline Parameters & $\begin{array}{c}\text { raw } \\
\text { vegetables }\end{array}$ & $\begin{array}{c}\text { Special } \\
\text { sauce }\end{array}$ & $\begin{array}{c}\text { Ord } \\
\text { inary } \\
\text { sauce }\end{array}$ & Rice & Potatoes \\
\hline MAG & $\begin{array}{c}(3.8 \pm 0.4) \\
10^{7 * a}\end{array}$ & $\begin{array}{c}(1.2 \pm 0.7) \\
10^{7 * * a}\end{array}$ & 0 & $\begin{array}{c}(3.2 \pm 0.1) \\
10^{5 * \mathrm{~b}}\end{array}$ & $(6.1 \pm 0.7) 10^{5 * \mathrm{~b}}$ \\
\hline $\begin{array}{c}\text { Total } \\
\text { coliforms }\end{array}$ & 0 & 0 & 0 & 0 & 0 \\
\hline $\begin{array}{c}\text { Fecal } \\
\text { coliforms }\end{array}$ & 0 & 0 & 0 & 0 & 0 \\
\hline $\begin{array}{c}\text { Staphy } \\
\text { lococcus } \\
\text { Aureus }\end{array}$ & $\begin{array}{c}(1.57 \pm 0.1) \\
10^{6}\end{array}$ & 0 & 0 & 0 & 0 \\
\hline Salmonella & 0 & 0 & 0 & 0 & 0 \\
\hline
\end{tabular}

*: CFU $/ g ;{ }^{*}$ : $\mathrm{CFU} / \mathrm{ml}$; MAG: mesophilic aerobic germs, Means with different letters in the same line are significantly different $(P$ $<0.05)$.

Table 2: Microbial load on the hands of producers, utensils and the diving area of YOP1.

\begin{tabular}{|c|c|c|c|}
\hline Parameters & $\begin{array}{c}\text { Hand of the } \\
\text { cookers }\end{array}$ & Ustensils & Dive Zone \\
\hline MAG $\left(\mathrm{CFU} / \mathrm{cm}^{2}\right)$ & 0 & 0 & $(9.1 \pm 0.8) 10^{6}$ \\
\hline Total coliforms $\left(\mathrm{CFU} / \mathrm{cm}^{2}\right)$ & 0 & 0 & 0 \\
\hline Fecal coliforms $\left(\mathrm{CFU} / \mathrm{cm}^{2}\right)$ & 0 & 0 & 0 \\
\hline $\begin{array}{c}\text { Staphylococcus } \\
\text { aureus }\left(\mathrm{CFU} / \mathrm{cm}^{2}\right)\end{array}$ & 0 & 0 & 0 \\
\hline Salmonella $\left(\mathrm{CFU} / \mathrm{cm}^{2}\right)$ & Absence & Absence & Absence \\
\hline
\end{tabular}

MAG: mesophilic aerobic germs , Means with different letters in the same line are significantly different $(P<0.05)$.

Microbial Load of Menus, Producers' Hands, Utensils and YOP2 Dive Zone

The raw vegetables (starter dish), the rice dish and the hands of the food service staff were free of microorganisms. The special sauce (intended for the company's staff), the ordinary sauce, the ready-to-eat potatoes, the kitchen utensils and the dishwashing area were contaminated with Mesophilic Aerobic Germs (MAG) with respective loads of $(2 \pm 0.3) 106 \mathrm{CFU} / \mathrm{ml} ; \quad(1.5 \pm 0.1) 106 \mathrm{CFU} / \mathrm{ml} ; \quad(1.5 \pm 0.2) 105$ CFU/g; (5 \pm 0.6$) 107 \mathrm{CFU} / \mathrm{cm} 2$ and $(2.6 \pm 0.3) 109 \mathrm{CFU} / \mathrm{cm} 2$ respectively. All samples are free of Salmonella (Tables $3 \&$ 4).

\section{Microbial Load of Menus, Producers' Hands, Utensils and Chu Dive Zone}

All samples tested were coliform-free except for attiéké. In addition, the samples of attiéké were contaminated with
Table 3: Microbial loads in YOP2 menus.

\begin{tabular}{|c|c|c|c|c|c|}
\hline Parameters & $\begin{array}{c}\text { raw } \\
\text { vegetables }\end{array}$ & $\begin{array}{c}\text { Special } \\
\text { sauce }\end{array}$ & $\begin{array}{c}\text { Ordinary } \\
\text { Sauce }\end{array}$ & Rice & Potatoes \\
\hline MAG & 0 & $\begin{array}{c}(2 \pm 0.3) \\
10^{6 * * a}\end{array}$ & $\begin{array}{c}(1.5 \pm 0.3) \\
10^{6 * * a}\end{array}$ & 0 & $(1.5 \pm 0.2) 10^{5 * \mathrm{~b}}$ \\
\hline Total coliforms & 0 & 0 & 0 & 0 & 0 \\
\hline Fecal Coliforms & 0 & 0 & 0 & 0 & 0 \\
\hline $\begin{array}{c}\text { Staphylococcus } \\
\text { aureus }\end{array}$ & 0 & 0 & 0 & 0 & 0 \\
\hline Salmonella & Absence & Absence & Absence & Absence & Absence \\
\hline
\end{tabular}

* : CFU /g; ** :CFU/ml ; MAG: mesophilic aerobic germs, Means with different letters in the same line are significantly different $(P$ $<0.05)$.

Table 4: Microbial load on the hands of producers, utensils and the diving area of YOP2.

\begin{tabular}{|c|c|c|c|}
\hline Parameters & $\begin{array}{c}\text { Hand of the } \\
\text { cookers }\end{array}$ & Ustensils & Dive Zone \\
\hline MAG $\left(\mathrm{CFU} / \mathrm{cm}^{2}\right)$ & 0 & $(5 \pm 0.6) 10^{7 \mathrm{a}}$ & $(2.6 \pm 0.3) 10^{9 \mathrm{~b}}$ \\
\hline Total coliforms $\left(\mathrm{CFU} / \mathrm{cm}^{2}\right)$ & 0 & 0 & 0 \\
\hline Fecal Coliforms $\left(\mathrm{CFU} / \mathrm{cm}^{2}\right)$ & 0 & 0 & 0 \\
\hline $\begin{array}{c}\text { Staphylococcus } \\
\left.\text { aureus } \mathrm{CFU} / \mathrm{cm}^{2}\right)\end{array}$ & 0 & 0 & 0 \\
\hline Salmonella $\left(\mathrm{CFU} / \mathrm{cm}^{2}\right)$ & Absence & Absence & Absence \\
\hline
\end{tabular}

MAG: mesophilic aerobic germs, Means with different letters in the same line are significantly different $(P<0.05)$.

all the germs tested with a predominance of Mesophilic Aerobic Germs which had a load of $(2 \pm 1.2) 104 \mathrm{CFU} / \mathrm{g}$. Staphylococcus aureus predominated in fried fish with a load of (2 \pm 0.1$) 104$ CFU/g while Mesophilic Aerobic Germs predominated in peanut sauce with a load of $(2.5 \pm 0.9) 105$ $\mathrm{CFU} / \mathrm{ml}$. All samples were free of Salmonella (Tables $5 \& 6$ ).

Table 5 : Microbial loads in CHU menus.

\begin{tabular}{|c|c|c|c|c|c|}
\hline Parameters & Fish Fry & $\begin{array}{c}\text { Peanut } \\
\text { Sauce }\end{array}$ & Fish soup & Rice & Attieke \\
\hline GAM & $\begin{array}{c}(3.5 \pm 2.1) \\
10^{4 * a}\end{array}$ & $\begin{array}{c}(2.5 \pm 0.9) \\
10^{5 * * \mathrm{~b}}\end{array}$ & $\begin{array}{c}(3.5 \pm 1.3) \\
10^{4 * * \mathrm{a}}\end{array}$ & $\begin{array}{c}(4 \pm 0.2) \\
10^{4 * \mathrm{a}}\end{array}$ & $(2 \pm 1.2) 10^{4 * \mathrm{a}}$ \\
\hline $\begin{array}{c}\text { Total } \\
\text { coliforms }\end{array}$ & 0 & 0 & 0 & 0 & $(5 \pm 2.4) 10^{3 *}$ \\
\hline $\begin{array}{c}\text { Fecal } \\
\text { coliforms }\end{array}$ & 0 & 0 & 0 & 0 & $(1 \pm 0.5) 10^{3 *}$ \\
\hline $\begin{array}{c}\text { Staphy } \\
\text { lococcus } \\
\text { aureus }\end{array}$ & $\begin{array}{c}(2 \pm 0.1) \\
10^{4 * \mathrm{a}}\end{array}$ & $\begin{array}{c}(5 \pm 2.7) \\
10^{3 * * \mathrm{~b}}\end{array}$ & $\begin{array}{c}(2 \pm 1.4) 10^{1} \\
* * \mathrm{c}\end{array}$ & $\begin{array}{c}(3 \pm 1.2) \\
10^{3 * \mathrm{~b}}\end{array}$ & $(6 \pm 1.1) 10^{3 * \mathrm{~b}}$ \\
\hline Salmonella & Absence & Absence & Absence & Absence & Absence \\
\hline
\end{tabular}

*: CFU $/ g$; **: CFU/ml ; MAG: mesophilic aerobic germs, Means with different letters in the same line are significantly different $(P$ $<0.05$ ).

Citation: Kouamé Kohi Alfred*, Bouatenin Koffi Maïzan Jean-Paul, Boli Zamblé Bi Irié Abel, Coulibaly Wahauwouélé Hermann, Djé Koffi Marcellin. Assessment of Hygiene in Collective Restaurants of Abidjan City (côte d'ivoire). 
Table 6: Microbial load on the hands of producers, utensils and the diving area of $\mathrm{CHU}$.

\begin{tabular}{|c|c|c|c|}
\hline Parameters & $\begin{array}{c}\text { Hand of the } \\
\text { cookers }\end{array}$ & Utensils & Dive zone \\
\hline MAG (CFU/cm $\left.{ }^{2}\right)$ & $(2.2 \pm 1.1) 10^{4 \mathrm{a}}$ & $(9 \pm 3.5) 10^{3 \mathrm{~b}}$ & $(5.4 \pm 3.1) 10^{4 \mathrm{a}}$ \\
\hline $\begin{array}{c}\text { Total coliforms (CFU/ } \\
\left.\mathrm{cm}^{2}\right)\end{array}$ & 0 & 0 & 0 \\
\hline $\begin{array}{c}\text { Fecal coliforms (CFU/ } \\
\left.\mathrm{cm}^{2}\right)\end{array}$ & 0 & 0 & 0 \\
\hline $\begin{array}{c}\text { Staphylococcus } \\
\text { aureus }\left(\mathrm{CFU} / \mathrm{cm}^{2}\right)\end{array}$ & $(2 \pm 0.9) 10^{3 \mathrm{a}}$ & $(2 \pm 0.3) 10^{3 \mathrm{a}}$ & $(8.4 \pm 0.6) 10^{3 \mathrm{~b}}$ \\
\hline Salmonella $\left(\mathrm{CFU} / \mathrm{cm}^{2}\right)$ & Absence & Absence & Absence \\
\hline
\end{tabular}

MAG: mesophilic aerobic germs, Means with different letters in the same line are significantly different $(P<0.05)$.

\section{Discussion}

Collective restaurants in companies and for hospital patients are becoming more and more indispensable nowadays. This allows the company to keep these employees on site and to control their food in order to avoid possible food poisoning problems. As for the hospitals, it allows them to follow and control the diet of their patients. However, poor hygiene management in these restaurants will be a source of problems for these companies and hospitals. The objective of this study was to assess the effectiveness of hygiene measures implemented in collective restaurants in the industrial zone of Yopougon and a University Hospital Center ( $\mathrm{CHU}$ ) in Abidjan in order to ensure the food safety of the guests.

The meals served as well as the hands of the providers and the diving areas of the restaurants YOP 1 and YOP 2 and $\mathrm{CHU}$ were of unsatisfactory microbiological quality according to the EC standard $n^{\circ} 2073 / 2005$ except for the fish soup served at the $\mathrm{CHU}$ restaurant. Similar results were found in Senegal by Tayou [10] in a study of the hygiene of modern collective restaurants in Dakar. The menus served by the restaurants in this study were colonized by microorganisms with loads exceeding the standard. The presence of these microorganisms reflects an exposure of the dishes to a soiled environment (air, spoon pot, plates etc.). Their presence also provides information on the state of property of food handlers, the conditions of conservation, the efficiency of the processes of treatment of products. It remains the best indicator of the application of good hygiene practices. Staphylococci are of human origin (skin, hair, nostrils, mouth) and indicate a lack of hygiene their presence in the dishes of these restaurants meant a lack of personal hygiene of food handlers. In addition, the microbiological quality of the meals served to consumers depends on the initial contamination of raw materials, the possibility of additional contamination at each stage of the production process, the possibility of residual contamination when a sanitizing treatment is applied, and the potential for multiplication of microorganisms present in the food [11]. A poorly adapted hygiene policy will result in an increase in biological contamination with the possibility of development of pathogenic microorganisms (Salmonella, coliforms, Staphylococci) with a risk of food poisoning [3]. The poor quality of the food produced by these companies could impact on the health of workers and consequently increase the rate of absenteeism and affect the performance of the companies.

\section{Conclusion}

In our country, collective restaurants are growing every day, particularly in companies. When the hygienic conditions of this catering are not respected, the result is that the meals present a considerable risk due to the possible presence of pathogenic microorganisms for the consumer. The distribution of meals to communities therefore requires special control in order to protect the health of the guests. The aim of this study was to assess the effectiveness of hygiene measures implemented in collective restaurants in the industrial zone of Yopougon and a University Hospital Center ( $\mathrm{CHU}$ ) in Abidjan to ensure the food safety of the guests. It was found that the dishes as well as the dishwashing areas and the hands of food handlers contained germs such as Staphylococcus and Mesophilic Aerobic Germs. The loads of these germs in most cases exceeded the EC standard No. 2073/2005. The dishes were therefore of unsatisfactory microbiological quality. The poor quality of the food from these companies could impact on the health of the workers and consequently increase the rate of absenteeism and affect the performance of the companies.

\section{Competing Interests}

The authors declare that there is no competing interest related to this manuscript

\section{Authors' Contributions}

This work was carried out in collaboration among all authors. Authors, KKA, BKJP, BZBIA, designed the study, performed the statistical analysis, wrote the protocol and wrote the first draft of the manuscript. Authors DKM managed the analyses of the study. Author KKA managed the literature searches. All authors read and approved the final manuscript

\section{Acknowledgements}

The authors would like to thank all the restaurants that

Citation: Kouamé Kohi Alfred*, Bouatenin Koffi Maïzan Jean-Paul, Boli Zamblé Bi Irié Abel, Coulibaly Wahauwouélé Hermann, Djé Koffi Marcellin. Assessment of Hygiene in Collective Restaurants of Abidjan City (côte d'ivoire). 
freely agreed to participate in this study.

\section{References}

1. Balde J (2002) Etude de la qualité microbiologique des repas servis à l'hôpital principal de Dakar thredvet. Dakar №1 P45.

2. Todd ECD, Greig J D, Bartleson CA, Michaels BS (2008) Outbreaks where food workers have been implicated in the spread of foodborne disease. Part 4. Infective doses and pathogencarriage. J. Food Prot 71: 2339-2373.

3. Barro N, Traoré AS (2003) L'impact de l'alimentation de rue sur la sécurité alimentaire au Burkina Faso. Atelier national de la Fondation SADAOC, réseau Burkinabé.

4. Magdevis YR, Antonio V, Elena C, Guiomar DP, Rosa MG, et al. (2012) Evaluation of hygiene practices and microbiological status of ready-to-eat vegetable salads in Spanish school canteens. J Sci Food Agric 92: 2332-2340.

5. Djeni NT, Kouame KA, Traore Y, Nevry KR, Dje KM (2014) Assessment of Knowledge, Attitudes and Practices of Food Handlers in Attieke Production Units in Relation to Food Hygiene and Safety in Côte d'Ivoire in 2012. Food and Nutrition Sciences 5: 896-904.

6. Kouame KA, Bouatenin KMJP, Djéni NT, Dje KM (2019)
Identification of hazards andcritical control points during attiéké (a fermented cassava product) process in Côte d'Ivoire. Letters in Applied Microbiology 70: 87-94.

7. Djéni NT, N'Guessan KF, Toka DM, Kouame KA, Dje KM (2011) Quality of attieke (a fermented cassava product) from the three main processing zones in Côte d'Ivoire. Food Res Int 44: 410-416.

8. Capita R, Alonso-Calleja MCB, Garcia-Fernandez MC (2001) Assessment of Baird Parker agar as screening test for determination of Staphylococcus aureus in poultry meat. Journal of Microbiology 39: 321-325.

9. Hendriksen RS (2003) Laboratory Protocols Level 1: Training Course Isolation of Salmonella. A Global Salmonella Surveillance and Laboratory Support Project of the World Health Organization, 4th ed. Geneva: WHO.

10. Toyou CMF (2007) Etude de I'hygiène dans la restauration collective commerciale moderne à Dakar. Mémoire pour l'obtention du Doctorat vétérinaire P50.

11. Dona GHA, Yénoukounmè EK, Mahunan FA, Ogouyôm HIA, Gertrude LMS (2019) Microbial contamination associated with the processing of grilled pork, a ready-to-eat street food in Benin. Journal of Food safety 40: e12731.

\footnotetext{
*Corresponding author: Kouamé Kohi Alfred, Email: kohi.kouame@csrs.ci

Next Submission with BGSR follows:

- Rapid Peer Review

- Reprints for Original Copy

- E-Prints Availability

- Below URL for auxiliary Submission Link: https://biogenericpublishers.com/submit-manuscript/
} 